\title{
Slag Foaming Fundamentals - A Critical Assessment
}

\author{
Rodolfo Arnaldo Montecinos de Almeida ${ }^{a}$, Deisi Vieira ${ }^{a}$, Wagner Viana Bielefeldt \\ Antônio Cezar Faria Vilela ${ }^{a}$
}

${ }^{a}$ Metallurgy Department, Federal University of Rio Grande do Sul, Av. Bento Gonçalves, 9500, 91501-970, Porto Alegre, RS, Brazil

Received: January 25, 2016; Revised: November 28, 2016; Accepted: January 25, 2017

\begin{abstract}
Slag foaming is part of steelmaking process and could bring several benefits: it helps to save energy, improves productivity, enhances the refractory service life, decreases noise pollution and protects the bath from nitrogen incorporation. Unfortunately, slag foaming is a highly dynamic process that is difficult to control. There are factors that limit the quality of the foam generated on the slag, such as: basicity, $\mathrm{FeO}$ content, surface tension, viscosity, carbon and oxygen injection. This paper aims to discuss the main factor that induces foaming, mathematical models proposed by different authors and the use of isothermal solubility diagram (ISD) to predict the foam quality.
\end{abstract}

Keywords: Foaming Slag, Electric Arc Furnaces, Steelmaking Slag

\section{Introduction}

One of the greatest consumers of electricity, electric arc furnaces (EAF), has been the subject of research in the steel production process. The use of fuel burners and oxygen injectors ${ }^{1}$ assists greater use of chemical energy for a possible reduction in electrical energy consumption. However, the loss of energy in the form of heat to the furnace walls occurs, and this reduces energy efficiency.

To reduce this loss of energy, studies were focused on the slag, especially on the phenomenon called foamy slag.

Foamy slag is widely used, not only because it allows energy to be saved, but due to the several advantages it offers, such as $2,3,4$ :

- Increased energy efficiency, since the heat from the arc is captured by the slag;

- Protection of the water panels and the roof from radiation;

- Decreased noise pollution;

- Decreased nitrogen incorporation by the bath.

This paper will make a critical assessment of the foamy slag phenomenon, analyzing the behavior of foamy slag with the variation of basicity, viscosity and chemical composition of the slag.

\section{Foamy Slag}

\subsection{Foamy Slag Formation}

Foamy slag formation can be divided into 3 steps (Figure 1). Step 1, which is $\mathrm{O}_{2}$ injection in liquid steel phase, step 2, which is carbon injection into the slag, and step 3, which is when $\mathrm{O}_{2}$ is injected into the slag.

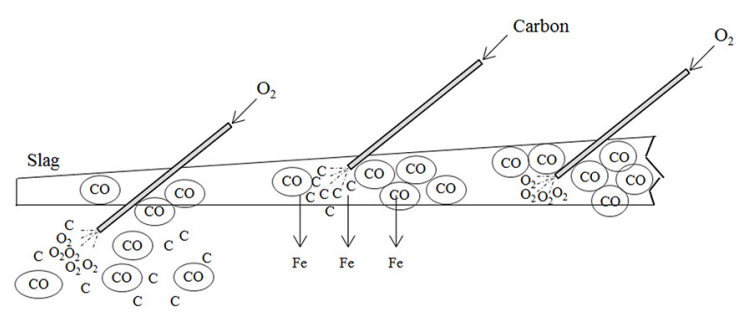

Figure 1: Diagram showing the formation of $\mathrm{CO}$ bubbles.

Initially, oxygen is injected into the molten metal (step 1). This oxygen reacts with the existing carbon (equation 1), forming $\mathrm{CO}$ bubbles. The oxygen also reacts with the $\mathrm{Fe}$ present in the bath (equation 2).

$$
\begin{aligned}
\mathrm{C}_{-}+\frac{1}{2} \mathrm{O}_{2} & \rightarrow \mathrm{CO} \\
\mathrm{Fe}_{(l)}+\frac{1}{2} \mathrm{O}_{2} & \rightarrow \mathrm{FeO}
\end{aligned}
$$

As Fe is lost in the form of oxide, carbon is injected into the slag (step 2), performing the iron oxide reduction reaction (equation 3). This step generates $\mathrm{CO}$ gas, and also causes $\mathrm{Fe}$ to return to the bath, improving furnace performance.

$$
\mathrm{C}+(\mathrm{FeO}) \rightarrow \mathrm{CO}+\mathrm{Fe}_{(l)}
$$

In step 3, oxygen is injected into the slag, to cause oxidation of the carbon present in the slag. In this step, carbon and oxygen can also be injected simultaneously, allowing better generation of $\mathrm{CO}$ and better foaming.

$$
(C)+\frac{1}{2} \mathrm{O}_{2} \rightarrow \mathrm{CO}
$$


In 1998, Pretorius ${ }^{6}$ stated that the $\mathrm{CO}$ generated by the bath decarburization reaction (Eq. 1) generally results in better foaming than the $\mathrm{CO}$ generated in the later steps. The bubbles formed by decarburization reaction in the bath are distributed more uniformly and have a smaller size, providing better stability to the foaming.

Matsuura ${ }^{7}$ found that the foam produced by iron oxide reduction reaction had smaller bubbles than those produced by reaction 1, producing more stable foam. He concluded that it is unclear if the decarburization reaction is as effective as the iron oxide reduction reaction in the generation of foam. If the $\mathrm{CO}$ from decarburization is neglected, the foaming can be controlled through the amount of carbon and oxygen injected during the process.

It is necessary to control the amounts of $\mathrm{C}$ and $\mathrm{O}$ added, because if excessive $\mathrm{O}$ is added, the yield may be reduced due to the loss of $\mathrm{Fe}$ to the slag in the form of $\mathrm{FeO}$.

Besides the amount, the location where the addition is being made is also important because each injection location has its peculiarities, such as decarburization when oxygen is injected into the bath and the return of $\mathrm{Fe}$, when carbon is injected into the slag. We note that a more in-depth study needs to be performed to establish at what location the injection generates better foaming, as authors hold divergent opinions ${ }^{6,7}$.

\subsection{Foaming index}

Ito and Fruehan ${ }^{8}$, found a relationship between superficial gas velocity and slag height, which is in equation 5 .

$$
\Sigma=\Delta H / \Delta V_{g}^{s}
$$

Where:

$\Delta \mathrm{H}=$ Variation in slag height $(\mathrm{cm})$;

$\Delta \mathrm{V}_{\mathrm{g}}^{\mathrm{s}}=$ Variation of superficial gas velocity $(\mathrm{cm} / \mathrm{s})$.

As the height of the slag grew linearly with the superficial velocity (Figure 2), and $\Sigma$ became constant after a certain superficial velocity was reached, they concluded that $\Sigma$ could be used as a foaming index.

\subsubsection{Mathematical models for the foaming index}

Several models have been proposed by researchers to define the foaming index using the physical properties of the slag.

Equation 6 includes the model of Ito and Fruehan ${ }^{8}$, which did not consider the presence of solid particles and bubble size.

$$
\Sigma=5.7 \times 10^{2} \mu / \sqrt{\gamma \rho}
$$

Where:

$\mu=$ viscosity (Pa.s);

$\gamma=$ surface tension $\left(\mathrm{N} . \mathrm{m}^{-1}\right)$;

$\rho=$ liquid density $\left(\mathrm{kg} \cdot \mathrm{m}^{-3}\right)$.

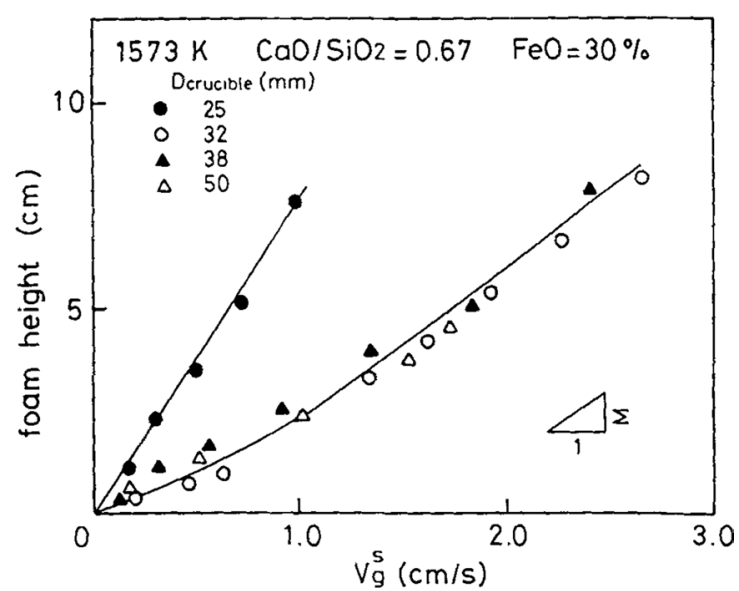

Figure 2: Relationship between slag height and superficial gas velocity for several crucible diameters.

Jiang and Fruehan ${ }^{9}$ carried out a dimensional analysis in order to find the relationship between the physical properties. Thus, they found more specific relationships (equations 7 and 8 ).

$$
\begin{array}{r}
\text { Basic Slag: } \Sigma=115 \mu / \sqrt{\rho \gamma} \\
\text { Acidic Slag: } \Sigma=0.93 \mu /\left(\rho^{2} / 3 \gamma\right)
\end{array}
$$

However, according to Stadler ${ }^{10}$, these relationships do not properly explain the foaming for acidic slag, either because of uncertainties associated with the measurement or prediction of slag properties.

In 1995, Zhang and Fruehan ${ }^{11}$ proposed new models that considered the bubble diameter $\left(\mathrm{D}_{\mathrm{b}}\right)$ formed in the foaming.

$$
\text { Basic Slag: } \Sigma=115 \frac{\mu^{1.2}}{\rho \gamma^{0.2} D_{b}^{0.9}}
$$

$$
\text { Acidic Slag: } \Sigma=10.3 \times 10^{4} \frac{\gamma^{1.2}}{\mu^{0.4} \rho^{1.4} D_{b}^{23}}
$$

For basic slag, the viscosity had a greater weight on the foaming index, while for acidic slag the most influential factor is surface tension.

In Ghag's ${ }^{12}$ model (equation 11), viscosity was considered to have a significant effect on the height of the slag, besides considering as well the effective elasticity of the liquid film that forms the bubble $\left(E_{f f}\right)$ and gravitational constant $\mathrm{g}$.

$$
\Sigma=1 X 10^{6} \frac{\mu E_{E f f}}{(\rho g)^{2} D_{b}^{3}}
$$

Skupien and Gaskell ${ }^{13}$ repeated the dimensional analysis performed by Jiang and Fruehan ${ }^{9}$ for other surface tension values, viscosities and densities, obtaining the following correlation:

$$
\Sigma=100 \frac{\mu^{0.54}}{\rho^{0.39} \gamma^{0.15}}
$$

$\mathrm{Kim}$ et al. ${ }^{2}$, suggested models for the $\mathrm{CaO}-\mathrm{SiO}_{2}-\mathrm{FeO}$ $\mathrm{Al}_{2} \mathrm{O}_{3}$ system and $\mathrm{CaO}-\mathrm{SiO}_{2}-\mathrm{FeO}-\mathrm{MgO}_{\text {sat. }}-\mathrm{X}\left(\mathrm{X}=\mathrm{Al}_{2} \mathrm{O}_{3}\right.$, 
$\mathrm{MnO}, \mathrm{P}_{2} \mathrm{O}_{5}$ and $\mathrm{CaF}_{2}$ ), showing the same parameters used in equation 7 .

$$
\text { Basic Slag: } \Sigma=214 \mu / \sqrt{\rho \gamma}
$$

$$
\mathrm{MgO}-\text { Saturated Slag: } \Sigma=999 \mu / \sqrt{\rho \gamma}
$$

Note that although dependent on the same physical properties, if compared with equation 7, Kim's model (equation 13) shows a large difference in the coefficient, which is due to differences between the properties used in each analysis ${ }^{2}$.

All foaming index models are based on the physical properties of the slag: viscosity $(\mu)$, surface tension $(\gamma)$ and slag density $(\rho)$. However, some authors ${ }^{14}$ found no relationship between foaming and slag properties, while others found no relationship between the experimental and theoretical results ${ }^{15}$.

It is important to draw attention to the presented models, as they were calculated for temperatures lower than the actual temperatures of the EAF Slag, around $1700^{\circ} \mathrm{C}$, besides having considered that the steel and slag are at the same temperature, but it is known that in the refining step, the temperatures are different, whereas the slag has a higher temperature than the liquid steel ${ }^{16}$.

\subsection{Influence of the viscosity}

As the foamy slag depends on the rise of bubbles formed by the described reactions, it was found that slag viscosity is extremely important to effective foaming. The increase in viscosity decreases the drainage rate of the liquid foam, giving the bubble a longer residence time, increasing foam height and stability ${ }^{3}$.

The effective viscosity of the slag can be calculated (equation 12) considering the presence of solid particles.

$$
\eta_{e}=\eta(1-1.35 \theta)^{-5 / 2}
$$

where:

$\eta_{\mathrm{e}}$ - effective viscosity of the slag (Pa.s)

$\eta$ - viscosity of the molten slag (Pa.s)

$\theta$ - fraction of precipitated solid phases

Figure 3 shows the effect that the viscosity has on the foaming index. An optimal slag is not completely liquid, whereas the presence of solid particles is crucial.

The solid particles act as nucleation sites for the bubbles, causing a large amount of small bubbles to be generated in the foamy slag ${ }^{6}$. Figure 3 shows that an increase in viscosity provides an increase in the foaming index, reaching a peak where the optimal slag is found. However, an excessive increase in viscosity forms crusty slag and the presence of solid particles begins to be harmful, because bubble ascension is impaired.

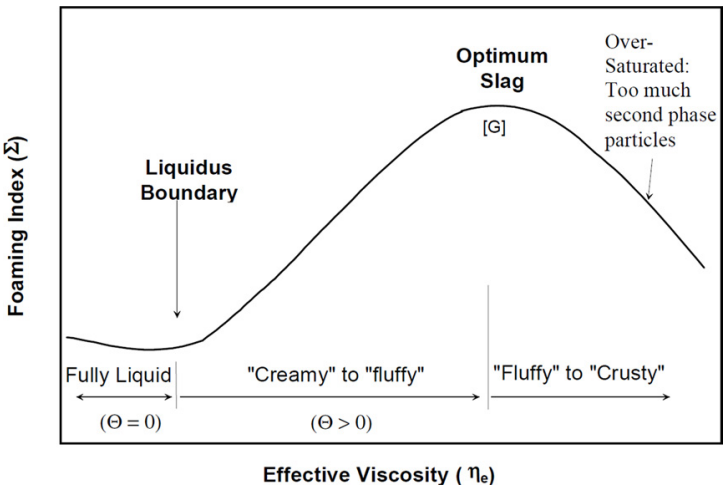

Figure 3: Relationship between the foaming index and effective viscosity.

Wu et al. ${ }^{17}$ demonstrated that for the obtained data, the surface tension and density have very little dependence with the chemical composition and the viscosity decreases as the $\mathrm{FeO}$ content increases, which would cause an decrease in the foaming index, strongly varying with basicity and $\mathrm{FeO}$ content.

It is risky to use the foaming index as the only parameter in analysis of foamy slag. All models are directly proportional to viscosity, and inversely proportional to density and surface tension. It is known that the viscosity vary with composition, and as said before, it would be a good approximation to use a constant surface tension and density in the model calculation. Then very viscous slag would have a high value of foamy index. This may lead to errors, because very viscous slag can be harmful to the foaming.

\subsection{Influence of Basicity}

Basicity has a strong influence on the foaming, both in the cases of acidic slag and basic slag, because the basicity is directly related to slag viscosity (Figure 4).
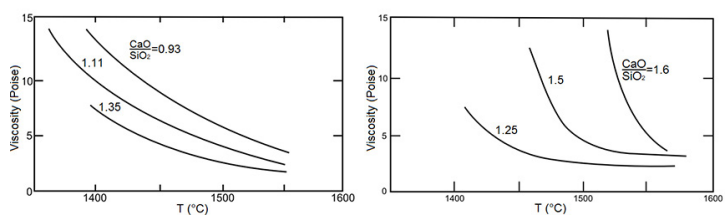

Figure 4: Influence of the $\% \mathrm{CaO} / \% \mathrm{SiO}_{2}$ ratio on viscosity in a) acidic slag and $b$ ) basic slag.

In acidic slag, increasing the $\mathrm{CaO}$ content causes a break in silica bonds causing a decrease in viscosity and, consequently, a decrease in the foaming index.

As for basic slag, an increase of the $\mathrm{CaO}$ content causes an increase in viscosity due to the saturation of these oxides, causing precipitation of the solid phase in the molten slag, causing to occur what was explained earlier in section 2.3. 
According to Morales et al. ${ }^{19}$, silica has surfactant properties in the steel slag, allowing solid particles to bind.

\subsection{FeO Influence}

The $\mathrm{FeO}$ present in the slag, in addition to representing a decrease in the furnace yield, also causes an effect that can be deleterious to the slag due to its fluxing characteristic, causing decreased viscosity.

Figure 5 shows the viscosity variation in a $\mathrm{CaO}-\mathrm{SiO}_{2}-$ $\mathrm{FeO}$ ternary diagram. The isobasicity line $\left(\mathrm{B}_{2}=1\right)$ shows that when the same ratio of $\% \mathrm{CaO} / \% \mathrm{SiO}_{2}$ is maintained, and the $\mathrm{FeO}$ content is increased, there is a reduction in viscosity.

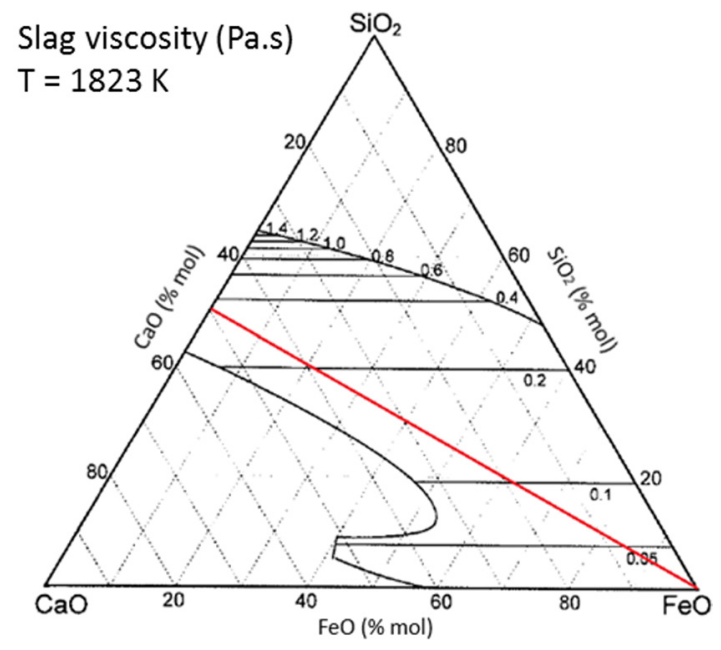

Figure 5: Viscosities of CaO-SiO2-FeO slag at $1823 \mathrm{~K}$ - calculated by Urbain's model. With an iso basicity line B2 $=1$.

This shows that the $\mathrm{FeO}$ content is extremely important, since there is a balance between the $\mathrm{FeO}$ created by the injected $\mathrm{O}_{2}$ and the $\mathrm{FeO}$ reduced by the carbon; if this balance is correct, there will be good foaming.

Corbari ${ }^{20}$, studied how the slag behaved for different $\mathrm{FeO}$ contents, with basicity $\mathrm{B}_{2}=1.2$, showing that for very high or very low $\mathrm{FeO}$ contents, the slag height and stability were lower than those found for intermediate $\mathrm{FeO}$ values (between $25 \%$ and $30 \%$ ). In these cases, the generated foam was still present after the gas generation decreased considerably (Figure 6).

Aminorroaya ${ }^{21}$ found that for basicity $\mathrm{B}_{2}=2.2$, the highest slag height occurred in $\mathrm{FeO}$ contents between $20 \%$ and $25 \%$. It also showed that for $\mathrm{FeO}$ contents between $20 \%-25 \%$, energy consumption was lower than that found when the $\mathrm{FeO}$ content was between $25 \%-30 \%$.

Therefore, it can be said that there is an optimum $\mathrm{FeO}$ content for foaming, but it was different for the two cases shown, $25-30 \%$ for Corbari ${ }^{20}$ and 20-25\% for Aminorraya ${ }^{21}$. The data from these authors show the dependence on the chemical composition, due to the difference in basicity (respectively 1.2 and 2.2).

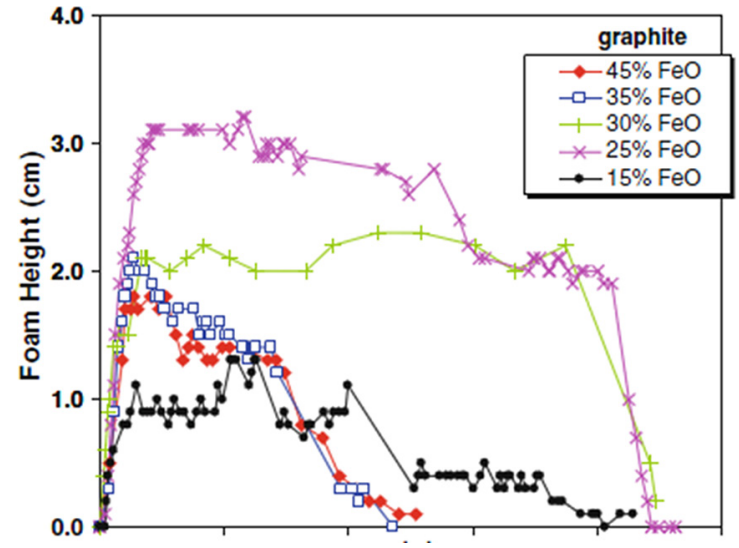

Figure 6: Relationship between slag height and time for different $\mathrm{FeO}$ contents.

\section{6. $\mathrm{MgO}$ Saturation}

$\mathrm{MgO}$ saturation ensures not only the presence of solid particles (as in the case of $\mathrm{CaO}$ ), but also that the consumption of the refractory is not excessive, as it prevents the slag from "stealing" $\mathrm{MgO}$ from the refractory.

To show the saturation levels, Pretorius ${ }^{6}$ developed isothermal solubility diagrams (ISD), as shown in Figure 7. The double saturation point shows the ideal condition to protect the furnace refractories when in contact with the slag.

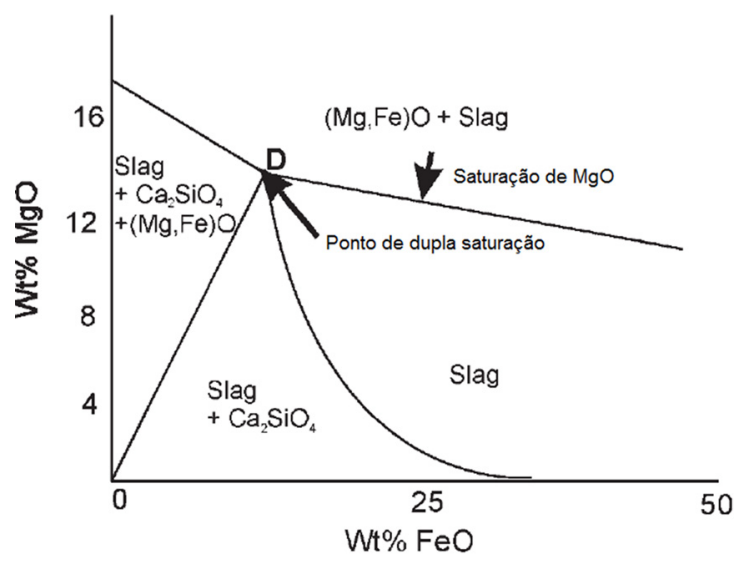

Figure 7: Generic Isothermal Saturation Diagram.

The ISDs show that the $\mathrm{MgO}$ saturation levels vary according to basicity and the $\mathrm{FeO}$ content (Figure 8 ). With the increase in basicity, the $\mathrm{MgO}$ levels required for saturation decrease. There is also a reduction in the variation of $\mathrm{MgO}$ saturation contents with the increase in $\mathrm{FeO}$ (line between points [a] and [b] in Figure 8).

Using the FactSage v.6.4 thermodynamic simulation software, Paulino ${ }^{22}$ made ISD's with the same conditions as those used by Pretorius, showing that the behavior of the saturation line could be different (Figure 9). This software 


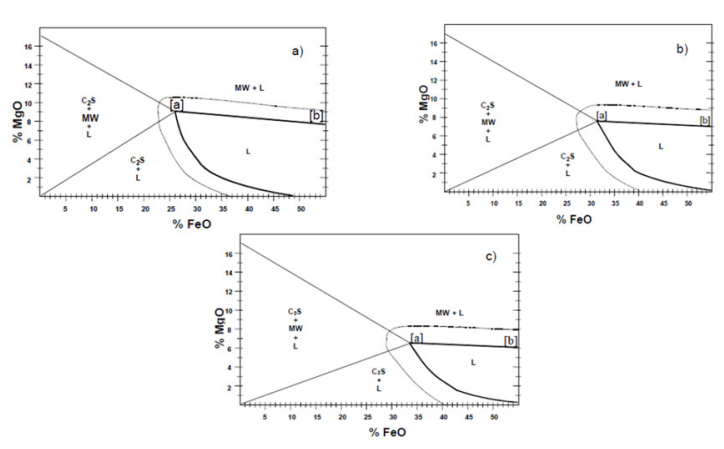

Figure 8: Isothermal saturation diagrams for different basicities (a) $\mathrm{B}_{3}=2.0$; (b) $\mathrm{B}_{3}=2.5$; (c) $\mathrm{B}_{3}=3.0$.

uses Gibbs energy minimization to calculate general phase diagram sections thermodynamically using the zero phase fraction line concept (ZPF). The program first scans the edge of the diagram to find the ends of the ZPF lines. Each line is then followed from beginning to end, using Gibbs energy minimization to determine the point at which a phase is just on the verge of being present ${ }^{23}$.
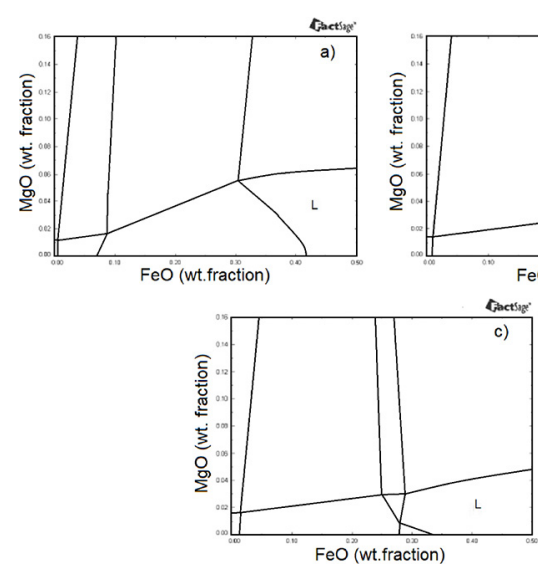

Figure 9: Isothermal saturation diagrams for different basicities (a) $\mathrm{B}_{2}=2.0$; (b) $\mathrm{B}_{2}=2.5$; (c) $\mathrm{B}_{2}=3.0$.

According to Paulino, the conditions for $\mathrm{MgO}$ saturation were the same for slag with low basicity $\left(\mathrm{B}_{2}<2.0\right)$. For higher basicity, the slope of the saturation line is positive, increasing the $\mathrm{MgO}$ saturation with the $\mathrm{FeO}$ contents, therefore the $\mathrm{FeO}$ effect in the $\mathrm{MgO}$ saturation line is the contrary to what was mentioned by Pretorius. Besides that, the $\mathrm{MgO}$ saturation and double saturation point values obtained by FactSage software were lower if compared to the values found previously.

Some of the differences may possibly be attributed to the chosen database. As the "FToxid", the main database considered, is composed by two databases: FToxid solution (FToxid53Soln.sda - contains oxide solutions); FToxid compound (FToxid53Base.cdb - contains all stoichiometric solid and liquid oxide compounds). However Paulino only used the solution model, rather than using compound solution model as well ${ }^{22}$.
Concerning the lowers $\mathrm{MgO}$ values obtained by the software, Tayeb et al. ${ }^{24}$ analyzed FactSage's ability to accurately predict $\mathrm{MgO}$ saturation. Figure 10 compares the current data, filled triangles, to calculated values of FactSage, open circles. It is apparent that FactSage underestimates $\mathrm{MgO}$ solubility by up $2.5 \mathrm{wt}$ pct, as compared to the measured data, especially at higher basicities, while showing reasonable agreement at lower basicities ${ }^{24}$.

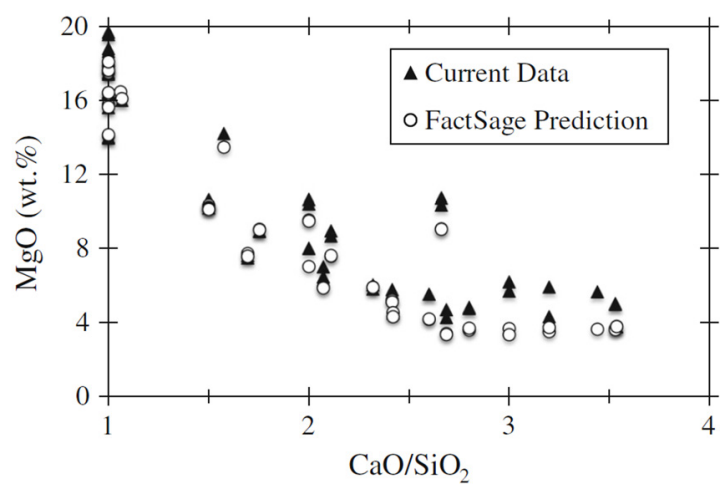

Figure 10: $\mathrm{MgO}$ solubility predicted by Factsage, open circles, and the measured solubility based on the chemical analysis results, filled triangles, as a function of the binary basicity at various $\mathrm{FeO}$ contents.

The ISDs are a quick and practical way to analyze $\mathrm{MgO}$ saturation and the quality of slag foaming, but some issues need to be considered, such as the presence of other oxides, because they may have large influence both on the liquid field and the double saturation point.

\subsection{Influence of superficial gas velocity}

For adequate foaming, the presence of $\mathrm{CO}$ bubbles is required; a high amount of bubbles together with good stability results in more efficient foaming. Superficial gas velocity is essential to obtain these results.

There are significant differences in the behavior of the foam generated by high and low gas velocity. These foams are called expanded slag and foamy slag, respectively ${ }^{3}$.

Figure 11 shows the "position" of the foamy slag and the expanded slag considering the fraction of gaps and superficial gas velocity. The fraction of gaps for both types of slag can be almost the same, making it easy to confuse the expanded slag with the foamy slag.

The main differences between the foamy slag and expanded slag are ${ }^{25}$ :

- $\quad$ Foamy slag: low superficial velocity; two distinct layers: a layer of foam over the layer of slag with few gaps; a large amount of bubbles, with thin walls, providing good stability, that is, the foam takes a long time to collapse even when gas generation decreases significantly.

- Expanded Slag: a uniform and mixed layer; the fraction of gaps varies according to the superficial gas 


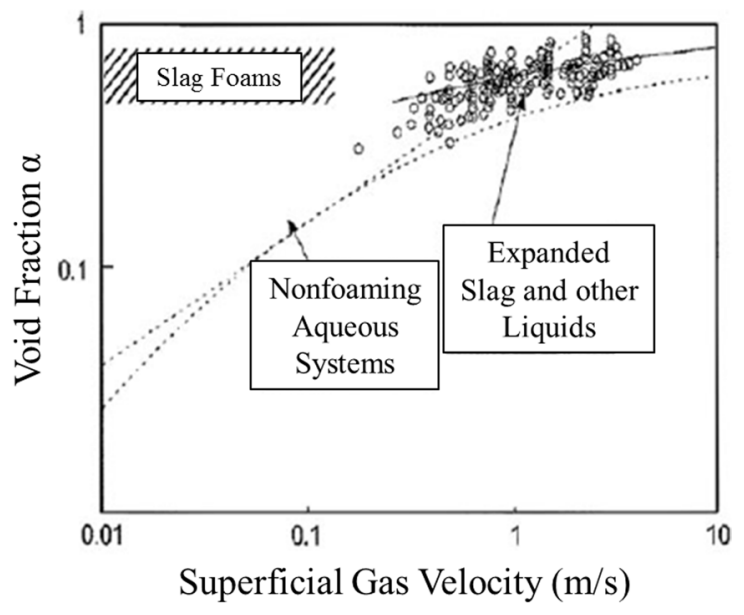

Figure 11: Summary of superficial gas velocity by fraction of gaps for foaming and non-foaming systems.

velocity (Figure 10); a turbulent appearance; large gaps with thick walls separating them, causing low stability, that is, when the gas generation decreases, the height of the slag starts to decrease considerably.

Zhu et al. ${ }^{3}$ concluded that as the superficial gas velocity increases, the slag height increase rate decreases dramatically. This occurs when the amount of slag that has still not foamed is consumed, causing a change in the mechanism causing a less stable foam.

Barella et al. ${ }^{26}$ stated that decrease in the height of the foam at high superficial gas velocity is associated with the increase of bubbles created in the gas diffuser. However, in industrial tests, the foam did not collapse at higher superficial velocities, since the bubbling process, under industrial conditions, led to the formation of fine bubbles that are not suitable for draining.

\subsection{Influence of the bubble size}

Another parameter that influences slag foaming is the bubble size. It is known that fine bubble generate better quality foaming than the foam generated by large bubbles ${ }^{26}$. This is because the fine bubbles generate spherical cells that are more stable, whereas the large bubbles generate polyhedral cells, which have reduced stability ${ }^{11}$.

The bubble size suffers influence of several factors, such as surfactant elements, superficial gas velocity and gas forming reactions.

Although there is disagreement among authors about the reaction that produces the finest bubbles and thus better foaming (section 2.1), it is clear the need for further study to better understand the creation of bubbles by the reactions shown in equations 1 to 3 .

According to Zhang ${ }^{11}$, the size of bubbles generated in the metal/slag interface depends on the activity of the surfactant element in the bath. This is because the bubble size is determined by the ratio between the thrust and interfacial tension, depending on the contact angle. Surfactant elements, such as sulfur, increase this angle, resulting in larger bubbles and less stable foaming.

A high superficial gas velocity is associated with larger bubbles, and with this, less stable foaming. This is because large bubbles favor the drainage of the fluid film, which reduces bubble stability ${ }^{26}$.

Some authors who tested different mathematical models, found no statistical evidence to justify the use of bubble size and the surface tension depression in place of the surface tension as a predictor of foaming ${ }^{10}$. But as stated before some authors found that foamy index was inversely proportional to the average bubble diameter ${ }^{11}$ or to the cube of the bubble diameter ${ }^{12}$.

\section{Conclusions}

Knowledge of the steel-making process is of utmost importance to understand the foamy slag phenomenon.

It is necessary to optimize several parameters so that slag foaming can have the best performance possible:

- A good amount of carbon and oxygen available so that the reactions that generate $\mathrm{CO}$ can occur, producing a large amount of bubbles;

- Slag saturation $(\% \mathrm{CaO}$ and $\% \mathrm{MgO})$ for high viscosity, with solid particles that nucleate $\mathrm{CO}$ bubbles;

- Optimal FeO content of the slag;

- Low superficial gas velocity, preventing the slag from becoming expanded slag.

Since it is a complex practice, the slag foaming phenomenon can still be extensively explored and developed by researchers in order to improve the steelmaking process in the steel industry.

\section{References}

1. Avila TA. Condicionamento de escórias em forno elétrico a arco para otimização das condições de espumação da escória e refino do aço. [Dissertation]. Belo Horizonte: Universidade Federal de Minas Gerais; 2011.

2. Kim HS, Min DJ, Park JH. Foaming behavior of $\mathrm{CaO}-\mathrm{SiO}_{2}-$ $\mathrm{FeO}-\mathrm{MgO}_{\text {satd }}-\mathrm{X}\left(\mathrm{X}=\mathrm{Al}_{2} \mathrm{O}_{3}, \mathrm{MnO}, \mathrm{P}_{2} \mathrm{O}_{5}\right.$, and $\left.\mathrm{CaF}_{2}\right)$ slags at high temperatures. ISIJ International. 2001;41(4):317-324.

3. Zhu TX, Coley KS, Irons GA. Progress in Slag Foaming in Metallurgical Processes. Metallurgical and Materials Transactions B. 2012;43(4):751-757.

4. Kozhuhov AA, Fedina VV, Merker EE. Study of the foaming of steelmaking slag and its effect on the thermal performance of an electric-arc furnace. Metallurgist. 2012;56(3):169-172.

5. Novak M, Straka J, Pribyl M. Influence of the Slag Foaming Process Applied in High Alloyed Steel Production on Refractory Wear of EAF at Pilsen Steel Melt Shop. In: Proceedings of $11^{\text {th }}$ Biennial Worldwide Conference on Unified International Technical Conference Refractories 2009 (UNITECR 2009); 2009 Oct 13-16; Salvador, BA, Brazil. 
6. Pretorius EB, Carlisle RC. Foamy slag fundamentals and their practical application to electric furnace steelmaking. In: Proceedings of the $16^{\text {th }}$ Process Technology Conference; 1998 Nov 15-18; New Orleans, LA, USA.

7. Matsuura H, Fruehan RJ. Slag Foaming in an Electric Arc Furnace. ISIJ International. 2009;49(10):1530-1535.

8. Ito K, Fruehan RJ. Study on the foaming of $\mathrm{CaO}-\mathrm{SiO}_{2}-\mathrm{FeO}$ slags: Part I. Foaming parameters and experimental results. Metallurgical Transactions B. 1989;20(4):509-514.

9. Jiang R, Fruehan RJ. Slag foaming in bath smelting. Metallurgical Transactions B. 1991;22(4):481-489.

10. Stadler SAC, Eksteen JJ, Aldrich C. An experimental investigation of foaming in acidic, high $\mathrm{Fe}_{\mathrm{x}} \mathrm{O}$ slags. Minerals Engineering. 2007;20(12):1121-1128.

11. Zhang Y, Fruehan RJ. Effect of the bubble size and chemical reactions on slag foaming. Metallurgical and Materials Transactions B. 1995;26(4):803-812.

12. Ghag SS, Hayes PC, Lee HG. The Prediction of Gas Residence Times in Foaming $\mathrm{CaO}-\mathrm{SiO}_{2}-\mathrm{FeO}$ Slags. ISIJ International. 1998;38(11):1216-1224.

13. Skupien D, Gaskell DR. The surface tensions and foaming behavior of melts in the system $\mathrm{CaO}-\mathrm{FeO}-\mathrm{SiO}_{2}$. Metallurgical and Materials Transactions B. 2000;31(5):921-925.

14. Hong L, Hirasawa M, Sano M. Behavior of Slag Foaming with Reduction of Iron Oxide in Molten Slags by Graphite. ISIJ International. 1998;38(12):1339-1345.

15. Lotun D, Pilon L. Physical Modeling of Slag Foaming for Various Operating Conditions and Slag Compositions. ISIJ International. 2005;45(6):835-840.

16. Turkdogan ET, Fruehan RJ. Fundamentals of Iron and Steelmaking. In: The AISE Steel Foundation. The Making, Shaping and Treating of Steel. Vol 2: Steelmaking and Refining Volume. Pittsburg: The AISE Steel Foundation; 1998.
17. Wu LS, Albersson GJ, Sichen D. Modelling of slag foaming. Ironmaking \& Steelmaking. 2010;37(8):612-619.

18. Coudurier L, Hopkins DW, Wilkomirsky I. Fundamentals of Metallurgical Processes. Oxford: Pergamon Press; 1978

19. Morales RD, Rodríguez-Hernandez H, Garnica-Gonzalez P, Romero-Serrano JA. A Mathematical Model for the Reduction Kinetics of Iron Oxide in Electric Furnace Slags by Graphite Injection. ISIJ International. 1997;37(11):1072-1080.

20. Corbari R, Matsuura H, Halder S, Walker M, Fruehan RJ. Foaming and the Rate of the Carbon-Iron Oxide Reaction in Slag. Metallurgical and Materials Transactions B. 2009;40(6):940948.

21. Aminorroaya-Yamini S, Edris H. The Effect of Foamy Slag in the Electric Arc Furnaces on Electric Energy Consumption. In: Proceedings of the $7^{\text {th }}$ European Electric Steelmaking Conference; 2002 May 26-29; Venice, Italy. p. 2447-2456.

22. Paulino MAS, Klug JL, Bielefeldt WV, Vilela ACF, Heck NC. Obtenção de escória espumante em forno elétrico a arco: determinação das composições para o sistema $\mathrm{CaO}-\mathrm{SiO}_{2}$ $\mathrm{MgO}-\mathrm{FeO}$. In: Proceedings of the $45^{\circ}$ Steelmaking Seminar - International; 2014 May 25-28; Porto Alegre, RS, Brazil.

23. Peltron AD. Thermodynamics and phase diagrams of materials. In: Korstorz G, ed. Phase transformations in Materials. New York: Wiley-VCH; 2001.

24. Tayeb MA, Assis AN, Sridhar S, Fruehan RJ. MgO Solubility in Steelmaking Slags. Metallurgical and Materials Transactions B. 2015;46(3):1112-1114

25. Gou H, Irons GA, Lu WK. A multiphase fluid mechanics approach to gas holdup in bath smelting processes. Metallurgical and Materials Transactions B. 1996;27(2):195-201.

26. Barella S, Gruttadauria A, Mapelli C, Mombelli D. Critical evaluation of role of viscosity and gas flowrate on sag foaming. Ironmaking \& Steelmaking. 2012;39(6):463-469. 